\title{
Time for tea, anyone?
}

\section{Turner, P McCrory, A Johnston}

\begin{abstract}
There have been suggestions that urine samples positive for benzoylecognine, the diagnostic metabolite of cocaine, may be the result of consumption Mate de Coca, a commercially available tea made from coca (Erythroxylon coca) leaves. The Jockey Club in Great Britain commissioned research into this subject as several jockeys have tested positive for benzoylecognine over the past few years. Urine samples collected at various time points within $24 \mathrm{~h}$ after ingestion of a $250 \mathrm{ml}$ infusion of Mate de Coca tea were analysed using three different methods. All samples tested positive for benzoylecognine.
\end{abstract}

$\mathrm{T}$ he Jockey Club has conducted random urine drug testing on jockeys in Great Britain since October 1994. ${ }^{1}$ During the period 1994-2004, over 2750 tests were carried out and a number of samples tested positive for benzoylecognine, the diagnostic metabolite of cocaine. Cases where a positive drug test is returned are heard by the Disciplinary Committee of the Jockey Club.

Over the years a number of possible explanations have been put forward by defence counsel to explain positive findings. These have included the handling of contaminated banknotes by the individual concerned and the consumption of tea made with "Mate de Coca" teabags. The Jockey Club has commissioned research into both these possible explanations and this report outlines the results of the "teabag" trial.

\section{AIMS}

Using a standard commercially available teabag of Mate de Coca, we set out to determine the quantity of cocaine that may be present in a cup of Mate de Coca tea and how long an athlete who has consumed such a tea may test positive on a standard urinary drug analysis.

\section{METHODS}

Mate de Coca is a commercially available tea made from coca (Erythroxylon coca) leaves (fig 1). An infusion was prepared by allowing one Mate de Coca teabag to be immersed in $250 \mathrm{ml}$ of boiling water for $25 \mathrm{~min}$. The bag was then removed and squeezed dry with the expelled water combining with the remaining infusion. A $5 \mathrm{ml}$ sample was taken for cocaine analysis using capillary electrophoresis. The subject, having given informed consent, then drank the remaining infusion. Urinary samples were collected for drug analysis prior to tea consumption and then at 2, 5, 8, 15, 20, 21, 24, 43, and $68 \mathrm{~h}$ after consumption of the tea.

Urine drug analysis was carried out using a one step immunometric test panel (Syva RapidTest d.a.u. 4; Syva, Dade Behring, Cupertino, CA). This is a simple immunological qualitative assay designed to test for the presence of cannabinoids, opiates, cocaine metabolites (benzoylecognine), and methyl amphetamine in human urine. Three drops of urine are added to a test strip and 5-10 min are allowed for the test to develop. If there are no drug

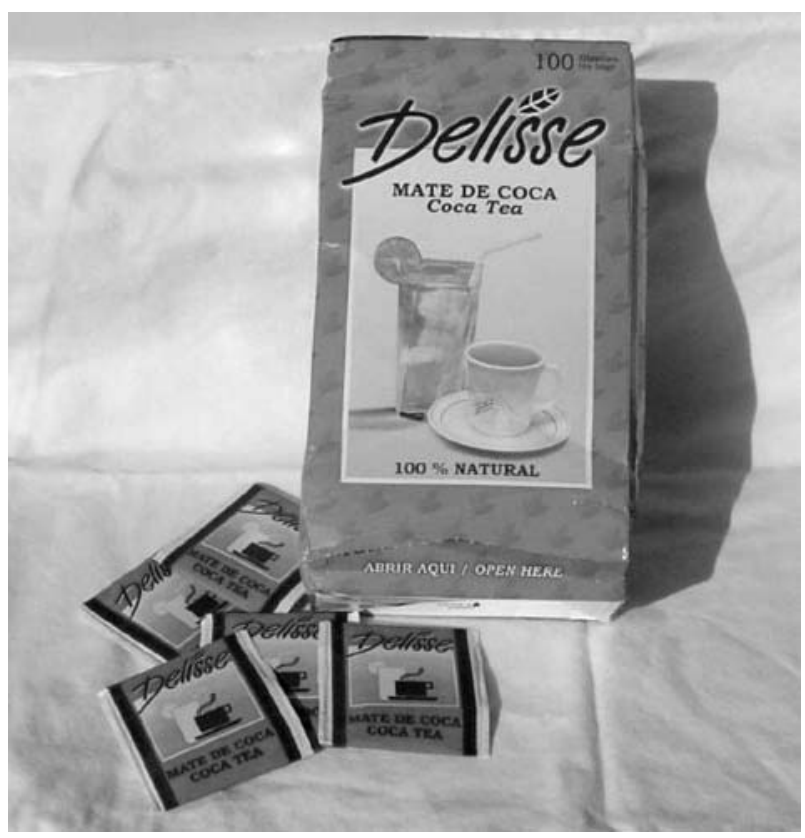

Figure 1 Mate de Coca teabags.

substances in the urine, then five bands appear, one for each drug, and a fifth band to confirm that the test strip is functioning correctly. If the urine does contain a drug substance, then the band associated with the drug does not develop.

The first three urine specimens after drinking the infusion were also analysed by two further methods, an immunological assay for the cocaine metabolite, benzoylecognine, from another manufacturer (Abbott TDx, Abbott Laboratories, Chicago, IL) and a specific chemical method based on gas chromatographic mass spectrometry.

\section{RESULTS}

\section{Cocaine in the infusion}

The amount of cocaine in the infusion was estimated by capillary electrophoresis at $2.5 \mathrm{mg}$. This is in keeping with previously reported values of between 3.4 and $4.8 \mathrm{mg}$ of cocaine in Peruvian teabags. ${ }^{2}$

\section{Urine analysis}

All samples collected in the $24 \mathrm{~h}$ period following ingestion of the infusion tested positive for the presence of the cocaine metabolite, benzoylecognine with all analysis methods. The results are set out in table 1 .

\section{DISCUSSION}

Throughout South America, particularly in Peru and Bolivia, there is a tradition of drinking medicinal tea made from the

Abbreviations: WADA, World Anti-Doping Agency 


\begin{tabular}{|c|c|c|c|}
\hline $\begin{array}{l}\text { Time after } \\
\text { drinking }\end{array}$ & $\begin{array}{l}\text { Syva Rapid } \\
\text { Test }\end{array}$ & Abbott TDx & $\begin{array}{l}\text { Gas } \\
\text { chromatographic } \\
\text { mass } \\
\text { spectrometry }\end{array}$ \\
\hline $\begin{array}{l}-15 \mathrm{~min} \\
2 \mathrm{~h} \\
5 \mathrm{~h} \\
8 \mathrm{~h} \\
15 \mathrm{~h} \\
20 \mathrm{~h} \\
21 \mathrm{~h} \\
24 \mathrm{~h} \\
43 \mathrm{~h} \\
68 \mathrm{~h}\end{array}$ & $\begin{array}{l}\text { Negative } \\
\text { Positive } \\
\text { Positive } \\
\text { Positive } \\
\text { Positive } \\
\text { Positive } \\
\text { Positive } \\
\text { Positive } \\
\text { Negative } \\
\text { Negative }\end{array}$ & $\begin{array}{l}\text { Not done } \\
\text { Positive } \\
\text { Positive } \\
\text { Positive }\end{array}$ & $\begin{array}{l}\text { Not done } \\
\text { Confirmed } \\
\text { Confirmed } \\
\text { Confirmed }\end{array}$ \\
\hline
\end{tabular}

coca leaf ( $E$ coca). This tea has been used for over 4000 years and is still considered a part of Andean culture. From ancient times, Mate de Coca was drunk at funerals and other rituals.

Public markets in South America sell loose coca leaves and most grocery stores sell commercial teabags made from coca. Mate de Coca, a clear tea similar to green Asian tea, is also commonly offered in restaurants. Although the teabag packaging reports benefits such as increased energy and improved digestion, most people who sample the product report little subjective effect at all.

In the 1980s, "de-cocainised" Mate de Coca tea was sold extensively in North America as "Inca Health Tea". This product was produced from the legitimate cultivation of Peruvian coca and licensed for pharmaceutical export by the Peruvian National Enterprise of Coca who sponsored a successful export drive into North American markets. As a result of these efforts, this tea has been increasingly available throughout the world.

Unlike the consumption of coca leaves or Mate de Coca tea, the illicit use of the chemical cocaine is a relatively recent development in the history of the coca plant. Apart from the criminal and regulatory issues related to the use of cocaine, this product is a banned ergogenic agent under the current World Anti-Doping Agency (WADA) regulations. The Jockey Club is not a signatory to the WADA convention and does not use the WADA list of banned substances or the WADA regulations. The Jockey Club does, however, undertake testing for products that impair performance in jockeys and the Jockey Club's list of banned agents includes cocaine. ${ }^{1}$

This study shows that a single teabag of Mate de Coca contains a significant amount of cocaine and that a subject who ingests a cup of Mate de Coca tea may test positive for
What is already known on this topic

There have been suggestions that urine samples positive for benzoylecognine, the diagnostic metabolite of cocaine, may be the result of consumption Mate de Coca, a commercially available tea made from coca (Erythroxylon coca) leaves.

\section{What this study adds}

A single teabag of Mate de Coca contains a significant amount of cocaine and a subject who ingests a cup of Mate de Coca tea may test positive for cocaine on urinary drug testing for at least $24 \mathrm{~h}$ following ingestion.

cocaine on urinary drug testing for at least $24 \mathrm{~h}$ following ingestion. It is also likely that with individual variation in drug metabolism and with the current highly sensitive methods used for drug testing at international level, the risk of a positive test may last beyond this $24 \mathrm{~h}$ time frame.

This knowledge has important implications for athletes who are subject to urinary drug screening whereby inadvertent or illicit use of such a product may result in drug sanctions.

\section{Authors' affiliations}

P McCrory, Centre for Health, Exercise and Sports Medicine, University of Melbourne, Australia

M Turner, The Jockey Club, 151 Shaftesbury Avenue, London WC2H 8AL, UK

A Johnston, Barts and The London Hospital Trusts, London, UK

Competing interests: none declared

Correspondence to: Dr Paul McCrory, Centre for Health, Exercise and Sports Medicine, University of Melbourne, Australia; paulmccr@ bigpond.net.au

Accepted 11 January 2005

\section{REFERENCES}

1 Turner M, McCrory P. Social drug policies for sport. Br J Sports Med 2003;37(5):378-80

2 Jenkins A, Llosa T, Montoya I, et al. Identification and quantification of alkaloids in coca tea. Forensic Sci Int 1996;77:179-89. 